\title{
Identification and Cloning of the ClpB Gene in Psychromonas arctica by Inverse PCR and Cassette PCR Technology
}

\author{
Aeran Choi, Joomi Na, Minsun Sung, Hana Im, ${ }^{\dagger}$ and Kyunghee Lee* \\ Department of Chemistry, Sejong University, Seoul 143-747, Korea. *E-mail: khlee@sejong.ac.kr \\ ${ }^{\dagger}$ Department of Molecular Biology, Sejong University, Seoul 143-747, Korea \\ Received January 18, 2010, Accepted February 5, 2010
}

\begin{abstract}
The family of $C l p B$ protein is a molecular chaperone which protects cellular proteins from being aggregated upon exposure to severe environmental stresses in association with DnaK/DanJ/GrpE in the ATP-dependent manner. In a psychrophilic bacterium which survives at a subzero temperature, any functional role of cold-active ClpB protein can be rather crucial. In order to identify a $C l p B$ encoding gene from a cold-adapted bacterium whose genome sequence has not been fully discovered, we have employed a series of PCR technologies, including a gradient PCR with homologous primers, an inverse PCR and a cassette PCR. The full sequence of PaclpB gene was successfully identified and compared with those of other psychrophilic species. We have further cloned the gene in E.coli expression systems and were able to induce $\mathrm{PaClpB}$ protein expression by IPTG, which help us understand a molecular mechanism for survival against extremely cold environments.
\end{abstract}

Key Words: ClpB, Psychophilic bacterium, Inverse PCR, IPTG induction

\section{Introduction}

Caseinolytic peptidase $\mathrm{B}(\mathrm{ClpB})$ is a member of the $\mathrm{AAA}^{+}$superfamily of ATPase whose homologous proteins ubiquitously exist in bacteria, yeasts and plants. ${ }^{1} \mathrm{ClpB}$ functions as a proteindisaggregating chaperone machine in an ATP-dependent manner. The ClpB family normally forms a hexameric ring structure as demonstrated by the crystal structure of Thermus thermophilus ClpB. ${ }^{2}$ Each monomer consists of an N-domain, two nucleotide binding domains (NBD1 and NDB2) and the middle domain (M domain). ATP binding and subsequent hydrolysis is indispensible for oligomerization as well as the chaperone function. ${ }^{3} \mathrm{ClpB}$ unfolds aggregated substrates and translocates them through the central channel of the hexameric ring complex to dissolve protein aggregates.

ClpB collaborates with a cognate Hsp70 system (DnaK, DanJ and $\mathrm{GrpE}$ ) to promote solubilization of aggregated proteins leading to the survival of bacteria against severe heat stress. ${ }^{4}$ Cellular functions of $\mathrm{ClpB}$ can be modulated in detail by the amount of a Hsp70 system. For example, two ClpB isoforms (ClpB95 and ClpB80) are translated from the same transcript in Escherichia coli. ClpB95 is more effective than ClpB80 as a chaperone protein especially when the cooperation with DnaK/DnaJ is not sufficient. ${ }^{5}$ Expression of $\mathrm{ClpB}$ is normally regulated not only by heat stress but also by a variety of stresses, such as osmotic shock and oxidative stress. ${ }^{6}$

It is of great interest whether or not a cold-active ClpB provides cold resistance for psychrophilic bacteria in the same way that it does for heat stressed ones. With the aim of understanding mechanisms of chaperones for cold-adaptation, psychrophilic bacteria growing in extremely cold areas, such as the Arctic or the Antarctic, have recently drawn much attention. ${ }^{7}$ Gene expression studies associated with cold acclimation in Listeria monocytogenes demonstrated that several stress proteins such as groEL, ClpB and ClpP were up-regulated. ${ }^{8}$ A proteomic study and an immunoprecipitation assay also showed that ClpB was up-regulated when E.coli cells with their cpn60/10 chaperonins deleted were complemented with Cpn proteins of the psychrophilic bacteria Oleispira Antarctica. ${ }^{9}$ Proteomic analysis of Chaetoceros neogracile, an Antarctic alga, upon cold treatment exhibited an increased level of DnaK and ClpB ${ }^{10}$ Several RNases and peptidases, including $\mathrm{ClpB}$ were generally up-regulated at subzero temperatures. ${ }^{11}$ So far the ClpB proteins from Colwellia psychrerythraea $34 \mathrm{H}$ and Pseudoalteromonas haloplanktis TAC125 have been reported as cold-adapted chaperones. ${ }^{12,13}$

In this work, we have identified the $\operatorname{clpB}$ gene from Psychromonas arctica (KOPRI22215) whose genome sequence is not yet discovered. Despite of no genome information available, a series of polymerase chain reactions (PCR), including a gradient PCR, an inverse PCR and a cassette PCR, were applied to target the paclp $B$ gene from the whole genomic DNA of $P$. arctica. ${ }^{14}$ We have further developed the expression systems of $\mathrm{PaClpB}$ protein in E.coli and were able to confirm the induced expression of PaClpB. Through identification and expression of $\mathrm{ClpB}$ from cold-adapted bacteria, it is our hope to have a better understanding for a molecular mechanism of survival against extremely cold environments.

\section{Experimental Section}

Bacterial stains and media. Psychrophilic bacterium (KOPRI22215) was donated by KOPRI, Korea Polar Research Institute, and tentatively identified as Psychromonas arctica based on $16 \mathrm{~S}$ rDNA gene sequence. $P$. arctica was grown at $15^{\circ} \mathrm{C}$ in Difco ${ }^{\mathrm{TM}}$ Marine broth medium. BL21(DE3) and BL21(DE3) pLysS were cultured in LB medium (Trypton $10 \mathrm{~g}$, Yeast extract $5 \mathrm{~g}, \mathrm{NaCl}$ $10 \mathrm{~g}$ per liter). Cell growth was monitored by reading O.D. at $600 \mathrm{~nm}$ with a UV-vis spectrophotometer (Hewlett Packard 8452A).

Gradient PCR amplification. Amplification of the specific 
DNA with no genome information available was carried out by a gradient PCR with sets of primers targeting conserved regions within the $c l p B$ genes of Psychromonas ingrahamii 37 and Psychromonas sp. CNPT 3. Total genomic DNA was extracted from collected cells by a Total DNA Extraction Kit (Gene All). The $1^{\text {st }}$ gradient PCR was performed in the 96 Gradient Thermal Block (Bioneer) with primer pairs, 5'- TTG AAA CCA GCA CTT GCC CGA GGT -3' (forwarding primer; F1) and 5' - TAC ATC AGG GTG TGC CTT TTC -3' (reversing primer; R1) targeting the sequences, $\mathrm{L}_{299} \mathrm{~K}$ P A L A R G 306 of NBD-1 and $\mathrm{E}_{680} \mathrm{~K} \mathrm{~A} \mathrm{H}$ P D V 687 of NBD-2. The PCR mixture consisted of $2 \mu \mathrm{L}$ of $10 \times$ Taq buffer (final concentrations: $10 \mathrm{mM} \mathrm{KCl}, 10 \mathrm{mM}\left(\mathrm{NH}_{4}\right)_{2}$ $\mathrm{SO}_{4}, 20 \mathrm{mM} \mathrm{MgSO}_{4}, 0.1 \mathrm{mg} / \mathrm{mL}$ nuclease-free BSA, $0.1 \%$ Triton $\mathrm{X}-100,20 \mathrm{mM}$ Tris-HCl pH 8.8), $2 \mu \mathrm{L}$ of each dNTP $(2.5$ $\mathrm{mM}), 0.4 \mu \mathrm{L}$ of each primer, $1 \mu \mathrm{L}$ of template DNA, and $0.4 \mu \mathrm{L}$ of Taq polymerase (Takara) in a final volume of $20 \mu \mathrm{L}$. The final product was analyzed in an agarose gel stained with ethidium bromide (EtBr) and the single band corresponding to a desired molecular weight was excised. The amplified DNA was purified from a gel piece with a Geneclean turbo kit (MP Bio) and sequenced by COSMO Genetech (Seoul, Korea). The second round of a gradient PCR was performed with a new set of primers designed from the upstream of homologous ATG start codon and the internal nucleotide sequence available (5'-TAT CGC CGA GAT GGT GTC-3', F2 and 5'-GCA GGG TCT GTT ATT TGC ACT TTA-3', R2).

Cassette PCR amplification. In order to identify a promoter region upstream of the $c l p B$ coding region, LA PCR in vitro cloning technology (TAKARA) was used with ligation of a Hind III cassette. ${ }^{15}$ The primers used were a cassette primer $(\mathrm{C} 1)$ and a specific primer (S1) [C1: 5'- GTA CAT ATT GTC GTT AGA ACG CGT AAT ACG ACT CA -3', S1: 5' - ACC TCG GGC AAG TGC TGG TTT CAA -3']. Annealing was done at $55^{\circ} \mathrm{C}$ for $30 \mathrm{sec}$ and an extension was performed at $72{ }^{\circ} \mathrm{C}$ for $4 \mathrm{~min}$ using Takara LA Taq polymerase. The subsequent $2^{\text {nd }} \mathrm{PCR}$ was carried out with the following primers [C2: 5'- CGT TAG AAC GCG TAA TAC GAC TCA CTA TAG GGA GA -3', S2: 5' GCC AAT CCT TCT ACA ATG - 3'].

Inverse PCR amplification. In order to identify the 3'-downstream region of the $c l p B$ gene, an inverse PCR technology was employed. With the internal nucleotide sequence available from the gradient PCR experiment, genomic DNA underwent digestion with restriction enzymes followed by ligation with T4 DNA ligase. The circularly ligated plasmid was then digested with Pst 1 and probed with primers, 5'-TAT AAC GAT GTG ATA ACG TC -3' (forwarding primer; F3) and 5'-CGT ATC GAT TCT GAA TT-3' (reversing primer; R3). A gradient PCR was performed by pfu polymerase (Promega) with an annealing time of $1 \mathrm{~min}$ and a polymerization time of $4 \mathrm{~min} 30 \mathrm{sec}$.

Cloning and expression of paclpB gene. For His-Tagged PaClpB expression, PCR amplification was carried out to produce the paclpB gene in its full length using primers designed to include restriction sites for Ndel and BamH1 [forwarding F3; 5'- AGA AAT TCA TAT GCG TTT AG -3', reversing R3; 5'- TTC ATG GGA TCC TTT ATG AC -3']. Amplified DNA bands were gel-purified, digested and ligated with T4 DNA ligase (NEB) into pET28a (Novagen, USA), previously digested with Ndeland BamH1, providing PaClpB/pET28a. BL21(DE3) cells transformed with $\mathrm{PaClpB} / \mathrm{pET} 28 \mathrm{a}$ were cultured in $\mathrm{LB}^{\mathrm{Kan}}$ at $25^{\circ} \mathrm{C}$ and induction with $0.5 \mathrm{mM}$ IPTG (isopropyl $\beta$-D-1thiogalactopyranoside) was done at $25^{\circ} \mathrm{C}$ for $5 \mathrm{hrs}$. Cells were harvested and lysed with sample buffer $[12 \mathrm{mM}$ Tris-Cl(pH 6.8), $5 \%$ glycerol, 4\% SDS, $2.88 \mathrm{mM} 2$-mercaptoethanol, $0.02 \%$ bromophenol blue] for separation on $12 \%$ SDS-PAGE followed by Coomassie Brilliant Blue (CBB) staining.

Analysis of PaClpB protein. The DNA sequence obtained by PCR was translated to the corresponding polypeptides using the Translate program (ExPASy Proteomic Server). The Promoter sequence was anticipated by Neural Network Promoter prediction (UC Berkeley). The protein sequence was investigated for the conserved domain using the Position-Specific Iterated BLAST (PSI-BLAST). Alignments with other ClpB proteins were examined using ClustalW2 (EBI server). The amino acid sequence of $\mathrm{PaClpB}$ was analyzed by PredictProtein (Columbia University) and SSPro (University of California at Irvine) designed to predict secondary structures.

Measurements of ATPase activity. The malachite green ATPase assay was used to measure ATP hydrolysis rate by $\mathrm{PaClpB}$ protein overexpressed. Crude protein extracts were prepared by resuspend frozen bacterial cells in buffer A $(20 \mathrm{mM}$ Tris, $10 \mathrm{mM}$ $\mathrm{KCl}, 5 \mathrm{mM} \mathrm{MgCl}_{2}, \mathrm{pH} 7.5$ ). Crude protein extracts were incubated at $4{ }^{\circ} \mathrm{C}$ for $30 \mathrm{~min}$ in reaction buffer $[50 \mathrm{mM} \mathrm{HEPES}, 30 \mathrm{mM}$ $\mathrm{KCl}, 30 \mathrm{mM} \mathrm{NH}_{4} \mathrm{Cl}, 1 \mathrm{mM}$ DTT, $5 \mathrm{mM} \mathrm{Mg}$ (acetate $\left.)_{2}\right]$ including $0.4 \mathrm{mM}$ ATP, and the amounts of $\mathrm{P}_{\mathrm{i}}$ released by hydrolysis were measured by the Malachite green assays. ${ }^{18}$

\section{Results and Discussions}

Identification of the $\operatorname{clpB}$ gene from $P$. arctica. In this study we developed a cloning strategy by employing several PCRs in order to search for a gene encoding the ClpB protein from KOPRI22215 (Fig. 1A). Genome sequence of KOPRI22215 has not been identified yet but it was tentatively named Psychromonas arctica. ${ }^{19}$ When no genome sequence is available, it is challenging to identify a specific gene and compare it with other homologous proteins. In general, a new gene encoding a specific protein can be searched by a series of purification protocols for the protein, followed up by measuring a specific activity, which are often time-consuming and troublesome. KOPRI22215 is of great concern to us because, even before a genome project for this strain begins, it serves as a good system to develop a methodology to clone a specific gene along with available genomic information of other Psychromonas strains, such as P. ingrahamii 37.

In order to search for a $\operatorname{clp} B$ gene from $P$. arctica with no genome information available, we applied several PCR technologies. We first designed a set of primers (F1 ad R1) targeting NBD-1 and NBD-2, which are known as the homologous regions among $\mathrm{AAA}^{+}$proteases. ${ }^{16}$ The paclpB gene between 915 and 2019 bp was first amplified by a gradient PCR using F1 and R1 primers and was further identified by DNA sequencing. Another set of primers (F2 and R2) were then designed to contain the ATG start codon region which was homologous in Psychromonas species and the identified internal region from the first PCR product. In order to discover the exact sequence of the start codon region, as well as the upstream promoter region, we 


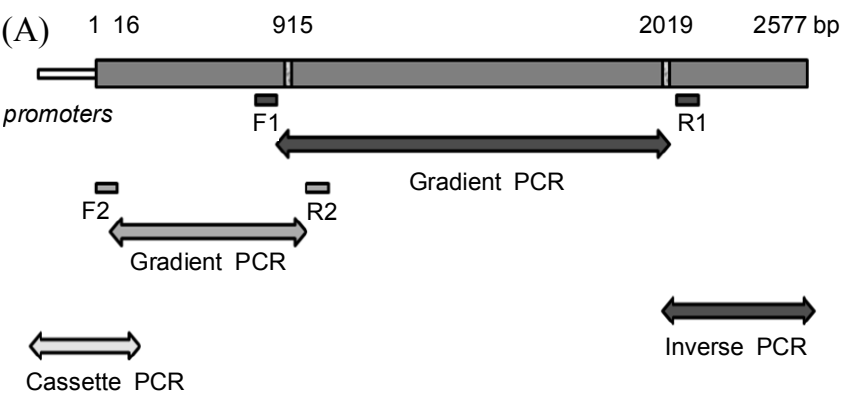

(B)

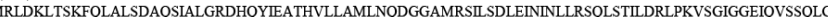
NTFNLCDKYAOKAKDKFISSEFLLVAVCEDKGELGQVLNKLGLTKSKVESSLKKIRQGQTVTDVNGDGPEQALEKYTIDLTERAAA GKLDPVIGRDDEVRRIVQVLQRRTKNNPVIIGEPGVGKTAIVEGLAQRINGEVPEGLKGKRVLSLDMGSLLAGAKYRGEFEERLKA VLAELNKEEGQVILFIDELHTMVGAGKGDGAMDASNMLKPALARGELHCVGATTLDEYRQYIERDAALERRFQKVIVDEPSVED ASIRRINDEOTLKSKGTEYKEIDEWKTEKAAL SGTONKOALEARIADEVASRASDITRMSELOYGRIPDIEKODLQNSDDE QEMTLLKHSVTENEIADILAHWTGIPVSKMLEGERDKLLKMEKYLHSQVVGQNEAIEAVSNAIRRSRAGLSDPDRPIGSFLFLGPTG VGKTESCKALANFLFDSVDNMVRDMSEFMEKHAVSRLVGAPPGYVGYEEGGYLTEAVRRKPYSVILDDEIEKAHPDVFNILLQV LDGRLTDGKGRTVDFRNTVIIMTSNIGSEIQEAFPRASYDDVKNTLLGILAKQFKPEFLNRIDETVVFHPLSEKHIKSIATIQLHAL

Figure 1. PCR strategies of identifying the paclpB gene. (A) The full length of paclpB gene ( $2577 \mathrm{bp}$ ) was amplified by a series of modified PCR technologies, including a gradient PCR, a cassette PCR and an inverse PCR. (B) The amplified gene was sequenced and translated to the corresponding amino acid sequence (ExPASY).

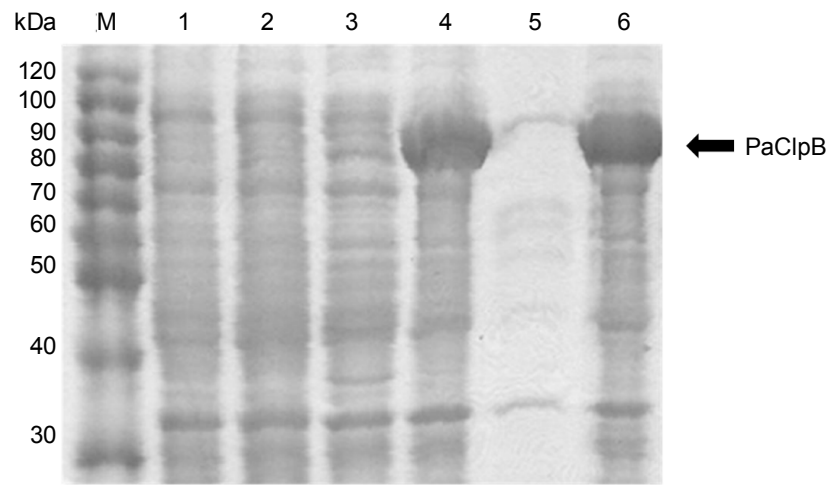

Figure 2. Induction of PaClpB expression. The paclpB gene was cloned into a His-tag expression system. Cells transformed with an empty vector (lanes 1 and 2) and PaclpB/pET28a were incubated without (lanes 1 and 3 ) and with $0.5 \mathrm{mM}$ IPTG (lanes 2 and 4). Inductions with IPTG were carried out at $25^{\circ} \mathrm{C}$ for $5 \mathrm{hrs}$. Expressed proteins were separated by centrifugation, yielding soluble (lane 5) and pellet fractions (lane 6).

carried out cassette PCR technology, by which we were able to identify the upstream $\sim 900 \mathrm{bp}$ sequence with the promoter region (ACTTTTAATTGTTCATAATTTATTCAATATATT CTTCCTTGTGACCTTGA; Pribnow box in italic). Finally, inverse PCR technology has been applied to uncover the 3'region of the $p a c l p B$ gene, which successfully completed the remaining 3'-sequences. The full DNA sequence of the paclpB gene is $2577 \mathrm{bp}$ long (GenBank: ACO90024) and the corresponding $\mathrm{PaClpB}$ protein consisted of 858 amino acid with the expected molecular weight of $95 \mathrm{kD}$ (Fig. 1B).

Comparison with homologous ClpB proteins. The amino acid sequence of the identified $\mathrm{PaClpB}$ protein shows $80 \%$ and $78 \%$ homology, respectively, to those of ClpB proteins from P.ingrahamii 37 and $P$. sp. CNPT3, upon sequence alignments by ClustalW2 (EMBL-EBI). It is interesting to note that P.ingrahamii

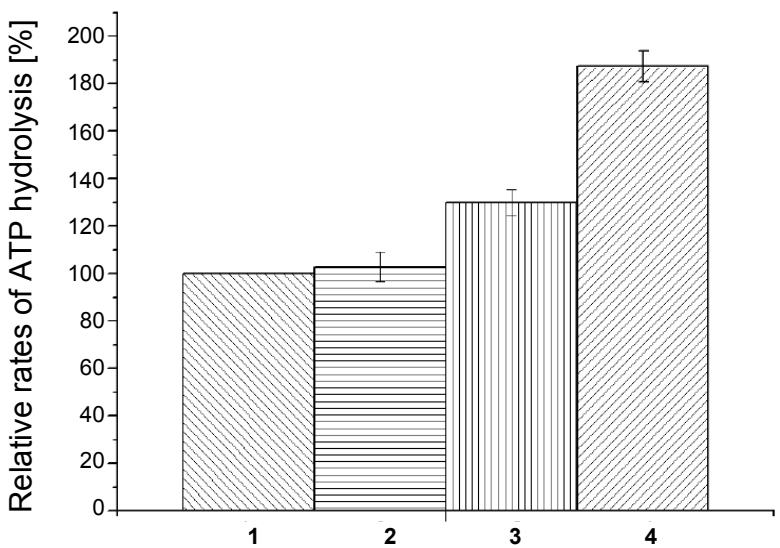

Figure 3. ATP hydrolysis activities of expressed $\mathrm{PaClpB}$ protein extracts. $P_{i}$ was released as a result of ATP hydrolysis at $4{ }^{\circ} \mathrm{C}$ and measured by the Malachite green method. Crude protein extracts assayed for ATP hydrolysis were prepared from E.coli cells transformed with pET28a vector alone (lanes 1and 2) and with PaclpB/pET28a (lanes 3 and 4). Cells were incubated in the absence (lanes 1 and 3 ) and the presence of IPTG (lanes 2 and 4 ) at $25^{\circ} \mathrm{C}$ for 5 hrs. Degrees of ATP hydrolysis were reported as percentages of ATP hydrolysis with a vector control as $100 \%$ (lane 1 ).

37 contains another copy of ClpB which has $43 \%$ homology and that $P$. sp. CNPT3 has another one with $34 \%$ homology. At this point we are not sure if $P$. actica has another copy of the $c l p B$ gene as shown in other Psychromonas species. PaClpB has a predominantly helical secondary structure as suggested by PredictProtein, consisting of an $\alpha$-helix $(59.9 \%)$, a $\beta$-sheet $(8.0 \%)$ and a loop (32.0\%). Domain analysis of PaClpB by SSPro (University of California at Irvine) ${ }^{17}$ also confirmed the presence of an N-domain, two Walker A motifs in the ATP binding sites and an Arginine finger domain, as reported for other $\mathrm{ClpB}$ proteins (data not shown).

Cloning of paclpB gene and induction of $\mathrm{PaClpB}$ expression. In order to express the His-tagged ClpB protein which can be later purified by a subsequent nickel-affinity chromatography, we amplified the full open reading frame of $p a c l p B$ gene by PCR with two primers deliberately designed to contain the Ndel and BamH1 sites. The amplified DNA was digested with NdeI and BamH1 before being ligated into the $\mathrm{pET} 28 \mathrm{a}$ vector with corresponding cohesive ends. Colonies with ligated plasmids were chosen and DNA sequencing was performed to verify the successful cloning of the paclpB gene in $\mathrm{pET} 28$ a to give $\mathrm{PaClpB} /$ pET28a. BL21(DE3)pLysS transformed with PaClpB/pET28a was then incubated with $0.5 \mathrm{mM}$ IPTG for $5 \mathrm{hrs}$ at $25^{\circ} \mathrm{C}$. The presence of overexpressed $\mathrm{PaClpB}$ proteins was examined in SDS-PAGE to display a strong band at $95 \mathrm{kDa}$ (lane 4 in Fig. 2). As a negative control, cells with empty pET28a vectors were induced with or without IPTG as well (lane 1 and lane 2 in Fig. 2). We have further attempted to purify $\mathrm{PaClpB}$ protein with Histags using $\mathrm{Ni}^{2+}$-affinity chromatography but have failed since $\mathrm{PaClpB}$ protein mostly remained in the pellet fraction as inclusion body (lane 6 in Fig. 2) upon centrifugation. Therefore, a biochemical approach to refold insoluble $\mathrm{PaClpB}$ protein, such as on-column refolding, has to be developed prior to affinity purification. 
The ATP hydrolysis activities of expressed $\mathrm{PaClpB}$ protein. Even if we failed to purify $\mathrm{PaClpB}$ protein due to the solubility problem, we asked if the expressed $\mathrm{PaClpB}$ proteins were functionally active. Since the domain analysis suggested that $\mathrm{PaClpB}$ contains the two ATP binding sites as in other ClpB proteins, we decided to check if the crude $\mathrm{PaClpB}$ protein extracts exhibited additional ATPase activities upon incubation with ATP. The Malachite green method was used to measure the amounts of $P_{i}$ released as a result of ATP hydrolysis at $4{ }^{\circ} \mathrm{C}$. As expected, the degree of ATP hydrolysis for $\mathrm{PaClpB}$ protein overexpressed (lanes 4 in Fig. 3) were 92\% higher than that of control (lanes 2 in Fig. 3) confirming that $\mathrm{PaClpB}$ protein expressed by IPTG was partly active. It is interesting to note that the ATP hydrolysis of uninduced $\mathrm{PaClpB} / \mathrm{pET} 28 \mathrm{a}$ crude extract (lane 3 in Fig. 3) also increased by $26 \%$, suggesting $\mathrm{PaClpB}$ proteins might have been auto-induced at a low level probably due to the presence of unknown inducer from the medium or the leakiness of the plasmid. More systematic kinetic analysis for the ATPase activity of PaClpB protein will be carried out along with purification of the protein.

It is noteworthy that cold-active DnaK from Shewanella sp. Ac10 provided the cold resistance of dnaK-null mutant of E.coli when treated at cold temperatures. ${ }^{20}$ It would be therefore interesting to see if the $\mathrm{PaClpB}$ obtained from psychrophilic bacteria provides additional cold-resistance phenotype when expressed in E.coli. It has been shown that the role of ClpB as a molecular chaperone correlates with the functional role of the Hsp70system, DnaK/DnaJ/GrpE. ${ }^{4}$ In order to examine cold-adaptation in $\mathrm{PaClpB}$-overexpressed cells, it is therefore required to control the translation of the $p a c l p B$ gene in the background of a dnaK-null mutant or a dnaK/tig deleted mutant (MC4100 $\Delta$ tig $\Delta$ dnaK) ${ }^{21}{ }^{21}$ Construction of the ClpB-expressing strain in the dnaK/tig deleted mutant is underway, which will examine the degree of cold-resistance provided.

Acknowledgments. The authors wish to thank KOPRI (Korea Polar Research Institute) for providing psychrophilic bacterium
(KOPRI22215). This work was supported by a grant (R01-2006000-11154-0) from the Basic Research Program of the Korea Science and Engineering Foundation.

\section{References}

1. Patel, S.; Latterich, M. Trends. Cell Biol. 1998, 8, 65.

2. Lee, S.; Sowa, M. E.; Watanabe, Y. H.; Sigler, P. B.; Chiu, W.; Yoshida, M.; Tsai, F. T. Cell 2003, 115, 229.

3. Mogk, A.; Schlieker, C.; Strub, C.; Rist, W.; Weibezahn, J.; Bukau, B. J. Biol. Chem. 2003, 278, 17815.

4. Watanabe, Y. H.; Yoshida. M. J. Biol. Chem. 2004, 279, 15723.

5. Chow, I. T.; Barnett, M. E.; Zolkiewski, M.; Baneyx, F. FEBS Lett. 2005, 579, 4242 .

6. Schirmer, E. C.; Glover, J. R.; Singer, M. A.; Lindquist, S. Trends Biochem. Sci. 1996, 21, 289.

7. Feller, G.; Gerday, C. Cell Mol. Life Sci.1997, 53, 830.

8. Liu, S.; Graham, J. E.; Bigelow, L.; Morse, P. D.; Wilkinson, B. J. Appl. Environ. Microbiol. 2002, 8, 1697.

9. Strocchi, M.; Ferrer, M.; Timmis, K. N.; Golyshin, P. N. Proteomics 2006, 6, 193

10. Park, S. K.; Jin, E. S.; Lee, M. Y. Cryo Letters 2008, 29, 351.

11. Berqholz, P. W.; Bakermans, C.; Tiedje, J. M. J. Bacteriol. 2009, 191, 2340.

12. Methé, B. A.; Nelson, K. E.; Deming, J. W.; Momen, B.; Melamud, E.; Fraser, C. M. Proc. Natl. Acad. Sci. USA 2005, 102, 10913.

13. Médigue, C.; Krin, E.; Pascal, G.; Barbe, V.; Bernsel, A.; Danchin, A. Genome Res. 2005, 15, 1325.

14. Ochman, H.; Gerber, A. S.; Hartl, D. L. Genetics 1988, 120, 621.

15. Isegawa, Y.; Sheng, J.; Sokawa, Y.; Yamanishi, K.; Nakagomi, O.; Ueda, S. Mol. Cell Probes 1992, 6, 467.

16. Barnett, M. E.; Zolkiewska. A.; Zolkiewski, M. J. Biol. Chem. 2000, 275, 37565 .

17. Pollastri, G.; Przybylski, D.; Rost, B.; Baldi, P. Proteins 2002, 47, 228.

18. Eichelberg, K.; Ginocchio, C.; Galan, J. J. Bacteriology 1994, 176, 4501.

19. Lee, Y. K.; Jung, H. J.; Lee, H. K. J. Microbiol. 2006, 44, 694

20. Yoshimune, K.; Galkin, A.; Kulakova, L.; Yoshimura, T.; Esaki, N. Extremophiles 2005, 9, 145.

21. Deuerling, E.; Patzelt, H.; Vorderwülbecke, S.; Rauch, T.; Kramer, G.; Bukau, B. Mol. Microbiol. 2003, 47, 1317. 